Journal of Agricultural Sciences
(Tarim Bilimleri Dergisi)

\title{
Genetic Characterization of Some Species of Vetch (VICIA L.) Grown in Turkey with SSR Markers
}

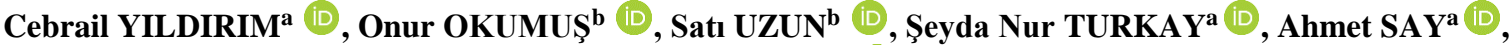 \\ Melike BAKIR ${ }^{a^{*}}$ (iD \\ ${ }^{\boldsymbol{a}}$ Department of Agricultural Biotechnology, Faculty of Agriculture, Erciyes University, Kayseri, 38039, TURKEY \\ ${ }^{b}$ Department of Field Crops, Faculty of Agriculture, Erciyes University, Kayseri, 38039, TURKEY \\ ARTICLE INFO \\ Research Article \\ Corresponding Author: Melike BAKIR, E-mail: melikecu@gmail.com \\ Received: 08 May2021 / Revised: 12 October 2021 / Accepted: 13 October 2021 / Online: 01 September 2022 \\ Cite this article \\ YILDIRIM C, OKUMUŞ O, UZUN S, TURKAY Ş N, SAY A, BAKIR M (2022). Genetic Characterization of Some Species of Vetch (VICIA L.) Grown in Turkey with SSR Markers. Journal \\ of Agricultural Sciences (Tarim Bilimleri Dergisi), 28(3):518-524. DOI: 10.15832/ankutbd.934655
}

\section{ABSTRACT}

The genus vetch (Vicia L.) is grown worldwide for fodder, hay, grain and silage, and rich in protein, mineral substances, vitamins and an essential source of roughage in animal husbandry. However, genetic characterization studies in vetch are minimal. In this study, the genetic characterization of a total 37 accessions of five vetches (Vicia L.) species was investigated using SSR markers. A total of 18 SSR markers were used, and eight of them were showed polymorphism and used for genetic analysis of vetch accessions. The total number of alleles was 35 , and the average number of alleles for each locus was determined as 4.38 . The average heterozygote rate was found to be 0.49 . The polymorphism information content (PIC) value varied between 0.23 and 0.77 , and the average value was 0.44 . Although almost a clear distinction was observed among the species, very high similarities were found between some cultivars within the same species. This similarity may be due to the narrow structure of the vetch genome or the inability of the SSR markers used in this study to distinguish the narrow structure of the vetch genome. The results reported here will be contributed to future germplasm management efforts and for comparative studies in vetch.

Keywords: Cross-amplification, Genetic variation, Microsatellites, Vetch, Vicia L.

\section{Introduction}

The genus Vicia L. belongs to the Fabaceae family (Van de Wouw et al. 2001; Renzi et al. 2020), and it is divided into two subgenera as Vicia and Vicilla (Kupicha 1976; Bozkurt 2009). The genus Vicia has 190 species worldwide (Davis 1970; Agar et al. 2006; Avcioglu et al. 2009) and, mainly distributed in Europe, Asia and North America, extending to temperate South America and tropical East Africa (Van de Wouw et al. 2001; Renna et al. 2014). The genus Vicia is represented by 59 species, 22 subspecies and, 18 varieties in Turkey (Davis 1970; Kiran et al. 2012) and five species and three subspecies of these are endemic in Turkey (Davis \& Plitmann 1970). Common vetch, Hungarian vetch, narbon vetch, bitter vetch and, hairy vetch are economically important Vicia species grown in Turkey (Genckan 1992). Vicia species are generally produced for fodder, hay, grain, silage, pasture, green manure and cover crop either in pure stands or in mixture with cereals as forage crops (Renzi et al. 2017; Kartal et al. 2020). Vetches have a very high feed value with their rich protein, mineral substances and vitamin content (Cheeke \& Shull 1985; Avc1oglu et al. 2009; Larbi et al. 2010; Renna et al. 2014). Vetches are also important crops for sustainable agriculture as they can fix atmospheric nitrogen and improve soil properties (Ibanez et al. 2020).

Determination of the diversity among genotypes is of great importance for breeding studies (Nunome et al. 2009). In recent years, molecular markers have increased in genetic diversity and characterization studies (O'Neill et al. 2003; Nunome et al. 2009; Ozsensoy \& Kurar 2012; Ertus et al. 2016; Zulkadir \& İdikut 2021). Among the molecular markers, SSR markers are the most widely used markers (Tautz 1989; Mengoni et al. 2000) because of the high abundance in the genome, high polymorphism information content, random distribution within the genome, and its co-dominant inheritance (Dutta et al. 2011). SRR markers developed in V. sativa subsp. sativa was used to determine the genetic diversity and relationships of different Vicia species and analyzed their transferability to Vicia genomes (Raveendar et al. 2015). Additionally, cDNA-SSR markers developed in Vicia sativa subsp. sativa was used genetic diversity of Vicia sativa subsp. sativa accessions (Chung et al. 2013). Besides, genetic characterization studies in Vicia ervilia (L.) Willd. (El Fatehi et al. 2016), Vicia narbonensis L. (Bouabid et al. 2018) and Vicia sativa L. (De la Rosa et al. 2021) were carried out using SSR markers. Also, RAPD (Potokina et al. 2000; Agar et al. 2006), AFLP (Potokina et al. 2002; Maul et al. 2011) and ISSR markers (Unverdi 2007; Bozkurt 2009) were used in characterization studies in the genus Vicia L. 
The present study aimed to reveal genetic diversity for registered Turkish vetch genotypes and some vetch lines using SSR markers. It is aimed that provided information about the genetic relationship among the vetch genotypes will help selection and more efficient utilization of the vetch genotypes in breeding programs and conservation of gene resources.

\section{Material and Methods}

\subsection{Plant Material and DNA Extraction}

The present study's Vicia species consist of 37 vetch genotypes (30 cultivars and 7 lines) obtained from different research centers in Turkey. A list of these genotypes and species and origin information were presented in Table 1.

Table 1- List of accessions used in this study

\begin{tabular}{|c|c|c|c|}
\hline No & Accessions & Species & Origin \\
\hline 1 & Yucel & Vicia sativa $\mathrm{L}$. & Eastern Mediterranean Agricultural Research Institute \\
\hline 2 & Ozveren & Vicia sativa $\mathrm{L}$. & Eastern Mediterranean Agricultural Research Institute \\
\hline 3 & Cumhuriyet-99 & Vicia sativa $\mathrm{L}$. & Aegean Agricultural Research Institute \\
\hline 4 & Selcuk-99 & Vicia sativa $\mathrm{L}$. & Aegean Agricultural Research Institute \\
\hline 5 & Alper & Vicia sativa $\mathrm{L}$. & Aegean Agricultural Research Institute \\
\hline 6 & Doruk & Vicia sativa $\mathrm{L}$. & Aegean Agricultural Research Institute \\
\hline 7 & Urkmez & Vicia sativa $\mathrm{L}$. & Aegean Agricultural Research Institute \\
\hline 8 & Ankara Moru-08 & Vicia sativa $\mathrm{L}$. & Field Crops Central Research Institute \\
\hline 9 & Ayaz-09 & Vicia sativa $\mathrm{L}$. & Field Crops Central Research Institute \\
\hline 10 & Zemheri-08 & Vicia sativa $\mathrm{L}$. & Field Crops Central Research Institute \\
\hline 11 & Alimoglu-2001 & Vicia sativa $\mathrm{L}$. & Field Crops Central Research Institute \\
\hline 12 & Bakir-2001 & Vicia sativa $\mathrm{L}$. & Field Crops Central Research Institute \\
\hline 13 & Farukbey-2001 & Vicia sativa $\mathrm{L}$. & Field Crops Central Research Institute \\
\hline 14 & Sari Elci & Vicia sativa $\mathrm{L}$. & Ankara University, Faculty of Agriculture, Department of Field Crops \\
\hline 15 & Tarman-2002 & Vicia narbonensis $\mathrm{L}$. & Field Crops Central Research Institute \\
\hline 16 & Bozdag & Vicia narbonensis L. & Aegean Agricultural Research Institute \\
\hline 17 & Balkan & Vicia narbonensis L. & Transitional Zone Agricultural Research Institute \\
\hline 18 & Kansur & Vicia pannonica Crantz & Field Crops Central Research Institute \\
\hline 19 & Anadolu Pembesi 2002 & Vicia pannonica Crantz & Field Crops Central Research Institute \\
\hline 20 & Oguz-2002 & Vicia pannonica Crantz & Field Crops Central Research Institute \\
\hline 21 & Tarim Beyazi -98 & Vicia pannonica Crantz & Field Crops Central Research Institute \\
\hline 22 & Dogu Beyazi & Vicia pannonica Crantz & East Anatolia Agricultural Research Institute \\
\hline 23 & Aygun & Vicia pannonica Crantz & East Anatolia Agricultural Research Institute \\
\hline 24 & Budak & Vicia pannonica Crantz & Transitional Zone Agricultural Research Institute \\
\hline 25 & Ege Beyazi-79 & Vicia pannonica Crantz & Aegean Agricultural Research Institute \\
\hline 26 & Beta & Vicia pannonica Crantz & Unknown \\
\hline 27 & Selcuklu-2002 & Vicia villosa Roth & Field Crops Central Research Institute \\
\hline 28 & Menemen-79 & Vicia villosa Roth & Aegean Agricultural Research Institute \\
\hline 29 & Efes-79 & Vicia villosa Roth & Aegean Agricultural Research Institute \\
\hline 30 & Segmen-2002 & Vicia villosa & Field Crops Central Research Institute \\
\hline 31 & Erac-2002 & Vicia villosa & Field Crops Central Research Institute \\
\hline 32 & Line -1 & Vicia ervilia & Ankara University, Faculty of Agriculture, Department of Field Crops \\
\hline 33 & Line -2 & Vicia ervilia & Ankara University, Faculty of Agriculture, Department of Field Crops \\
\hline 34 & Line -9 & Vicia ervilia & Ankara University, Faculty of Agriculture, Department of Field Crops \\
\hline 35 & Line -10 & Vicia ervilia & Ankara University, Faculty of Agriculture, Department of Field Crops \\
\hline 36 & $\begin{array}{l}\text { Usak-Esme-1 } \\
\text { (cream seed coated line) }\end{array}$ & Vicia ervilia & Usak province, Turkey \\
\hline 37 & $\begin{array}{l}\text { Usak-Esme-2 } \\
\text { (blackish seed coated line) }\end{array}$ & Vicia ervilia & Usak province, Turkey \\
\hline
\end{tabular}

*lines: $14,32,33,34,35,36,37$

\subsection{SSR analysis}

Genomic DNA was isolated from fresh, young seedlings according to the protocol described by Lefort et al. (1998) with minor modifications. The quality and quantity of the extracted DNA were determined in NanoDrop ${ }^{\circledR}$ ND-1000 Spectrophotometer (NanoDrop Technologies, Wilmington, DE, USA) and agarose gel electrophoresis (1\%). A total of 18 SSR loci were used in this study. Thirteen of these (Lc_MCu 11, Lc_MCu 17, Lc_MCu41a, Lc_MCu 43, Lc_MCu47a, Lc_MCu71, Lc_MCu73, Lc_MCu75, Lc_MCu78, Lc_MCu83, Lc_MCu85, Lc_MCu95, Lc_MCu97) were developed in lentil (Bak1r \& Kahraman 2019) and five (KF008505, KF008507, KF008512, KF008526, KF008536) were developed for common vetch genetic studies (Chung et al. 2013) (Table 2). 
Table 2- List of SSR markers used in the study

\begin{tabular}{|c|c|c|}
\hline Locus & Primer sequences (5' $\rightarrow 3^{\prime}$ ') & $\operatorname{Tm}\left({ }^{\circ} \mathrm{C}\right)$ \\
\hline Lc_MCu11F & GAGTGGGAAGGAGACCACAA & 54 \\
\hline Lc_MCu11R & CGTGGTCAGGAGAGGAAATA & \\
\hline Lc_MCu17F & GAAAGACAAAGAACGTGATAGAAGG & 58 \\
\hline Lc_MCu17R & TGACCGTTGTTCCCAAATTC & \\
\hline Lc_MCu41aF & TGTGTGAGGAAGATGATGAA & 48 \\
\hline Lc_MCu41aR & AAGGAGTTCACACACACACA & \\
\hline Lc_MCu43F & TCATAAAGCATTTGGCTAAAACA & 50 \\
\hline Lc_MCu43R & CGCAAGCCTCAAGCCTATAA & \\
\hline Lc_MCu47aF & TTAGTTCGGAGAGCGTTTAG & 48 \\
\hline Lc_MCu47aR & TGAAGAAGTGGAGGAGAAGA & \\
\hline Lc_MCu71F & СТСТСТАACACTATCACGCTCA & 60 \\
\hline Lc_MCu71R & GAAGGAGTAGACAGGGAGAAG & \\
\hline Lc_MCu73F & TGGGACTTGAGAGAAGATTG & 58 \\
\hline Lc_MCu73R & GTCTCTCTСССТССТCАTTT & \\
\hline Lc_MCu75F & TCACGTCTTCTAGGAAGTCTCT & 55 \\
\hline Lc_MCu75R & ATTGAGGATCCTGAGGTTG & \\
\hline Lc_MCu78F & GGTTGGGTGACAGTGAGA & 50 \\
\hline Lc_MCu78R & AACGAAGGAGTCCCAAAC & \\
\hline Lc_MCu83F & ATCCTAAGCAAAGAATGACG & 55 \\
\hline Lc_MCu83R & AAGGAGTCCACATACAAAACC & \\
\hline Lc_MCu85F & CAGTCGTTTCATTCTCTTCC & 55 \\
\hline Lc_MCu85R & GAGTACGGAACCGGAGAT & \\
\hline Lc_MCu95F & CCTTCACTCTACTCTCTCGTTC & 55 \\
\hline Lc_MCu95R & СTTTCATTCACTCGTTCCTC & \\
\hline Lc_MCu97F & CTACTCTCTCGTTCAGATCCTC & 55 \\
\hline Lc_MCu97R & ATCCATAAGAGCCCGTATTT & \\
\hline KF008505F & ATCCATGCCTCTTTTGCC & 55 \\
\hline KF008505R & AGCCTCATTTCAGCAGCA & \\
\hline KF008507F & TGGTTTCTTTCTAAAGGGGTG & 55 \\
\hline KF008507R & CGGCTCGATGGACAGTAG & \\
\hline KF008512F & GGCCGGTATTCGTCAACT & 55 \\
\hline KF008512R & CCCCGTATTTTCTCGGTC & \\
\hline KF008526F & CACTGTGACTCAGTTTCGTTG & 55 \\
\hline KF008526R & CGATTTTGAACCCTAACCG & \\
\hline KF008536F & TGGTGGACGTCACTATGGA & 55 \\
\hline KF008536R & CATGGTGCTTCCGACAAT & \\
\hline
\end{tabular}

PCR amplifications were performed using an M13-tailed primer according to method developed by Schuelke (2000). A tail M13 (-21), (TGTAAAACGACGGCCAGT) universal sequence was added to the 5' end of each forward primers. PCR amplifications were performed in $20 \mu \mathrm{L}$ reaction mixture containing 15 ng genomic DNA, $0.1 \mu \mathrm{M}$ of each SSR primer, $0.1 \mu \mathrm{M}$ labelled M13 (-21) universal primer, $0.2 \mathrm{mM}$ dNTP, 1X DreamTaq Green Buffer (contains $2 \mathrm{mM} \mathrm{MgCl} 2$ at a concentration of $2 \mathrm{mM}$ ) (Thermo Scientific, Waltham, MA, USA) and 0.5 U DreamTaq DNA Polymerase (Thermo Scientific, Waltham, MA, USA). Reaction mixtures without DNA were included as negative controls. PCR amplification was performed using the BioRad T100 thermocycler device. The amplification program conditions involved an initial step of 3 min at $94{ }^{\circ} \mathrm{C}$, followed by 35 cycles of $1 \mathrm{~min}$ at $94{ }^{\circ} \mathrm{C}, 1 \mathrm{~min}$ at $48-60^{\circ} \mathrm{C}, 2 \mathrm{~min}$ at $72{ }^{\circ} \mathrm{C}$, followed by 8 cycles of 1 min at $94{ }^{\circ} \mathrm{C}, 1 \mathrm{~min}$ at $53{ }^{\circ} \mathrm{C}, 2 \mathrm{~min}$ at 72 ${ }^{\circ} \mathrm{C}$, and a final step of $10 \mathrm{~min}$ at $72{ }^{\circ} \mathrm{C}$. PCR products were controlled by $\% 2$ agarose gel electrophoresis.

The M13 (-21) was 5'-fluorescently tagged with HEX, FAM or ROX to facilitate multiplexing. A set of three PCR products $(0.5 \mu \mathrm{L}$ each) was mixed with $0.5 \mu \mathrm{L}$ GeneScan-600 LIZ size standards (Applied Biosystems, USA) and 9.5 $\mu \mathrm{L}$ Hi-DiTM formamide (Applied Biosystems) and denatured at $95^{\circ} \mathrm{C}$ for $5 \mathrm{~min}$, chilled on ice and electrophoresed on the Applied Biosystems Prism 3500 Genetic Analyzer System (Applied Biosystems, USA). GENEMAPPER software v5.0 (Applied Biosystems, USA) was used to determine fragment size.

\subsection{Statistical analysis}

For each locus, the expected heterozygosity (He), observed heterozygosity (Ho) and the polymorphism information content (PIC) (Nei 1973) were calculated with PowerMarker V3.025 software (Liu \& Muse 2005). The neighbour-joining (NJ) and UPGMA (unweighted pair-group method using arithmetic average) were used to construct and draw a dendrogram from the genetic similarity matrix by using the MEGA6 (Tamura et al. 2007) and PowerMarker software programs. 


\section{Result and Discussion}

A total of 37 vetch accessions were analyzed using 18 SSR loci. Although the polymorphism rates of 18 loci were very high in the developed plants, only 8 showed polymorphism and used for analysis. Eight among the 13 markers developed by Bakır \& Kahraman (2019) for lentil genetic analysis, namely Lc_MCu41a, Lc_MCu47, Lc_MCu71, Lc_MCu73, Lc_MCu75, Lc_MCu78, Lc_MCu83 and Lc_MCu85 could not be amplified, and Lc_MCu43 marker created multiple bands and discarded from the study. The polymorphism ratio of Lc_MCu11, Lc_MCu17, Lc_MCu95 and Lc_MCu97 markers developed in the same study was found similarly high. These results also showed that lentil SSR markers used in this study are transferable for vetch species and can use for genetic analysis in vetch. The rest of 5 SSR markers were chosen among the common vetch transferable 36 SSR markers developed for common vetch (Chung et al. 2013; Raveendar et al. 2015). Among these markers, while KF008505, KF008507, KF008512, and KF008526 loci were showed similar polymorphism; however, the KF008536 locus was not amplified.

A total of 35 alleles were generated from 37 vetch accessions using 8 SSR loci. The number of alleles per locus varied between 2 and 8, and the average locus value was found 4,38. The lentil SSR locus Lc_MCu17 had the highest number of alleles with 8 alleles (Table 3). The number of alleles per locus that we obtained was found to be low compared to the results obtained by Chung et al. (2013) in common vetch and Raveendar et al. (2015) in vetch species and but similar to the results obtained by Renzi et al. (2020) in hairy vetch and. However, the average locus value was similar to the results obtained by Renzi et al. (2020) in hairy vetch, but was lower than the results obtained by Chung et al. (2013) in common vetch and Raveendar et al. (2015) in vetch species. It is thought that the difference in the results obtained was due to the number of markers and the size of the population.

The expected heterozygosity value (He) obtained from this study ranged between 0.27 (Lc_MCu97 and Lc_MCu11) and 0.79 (Lc_MCu17) with an average of 0.49 . The observed heterozygosity value (Ho) varied between 0.00 (Lc_MCu97 and Lc_MCu11) and 0.27 (KF008507) with the average 0.10 (Table 3). The value results of this study were similar to Chung et al. (2013), Raveendar et al. (2015), but were higher than Renzi et al. (2020). Ho values obtained from this study were found lower than Chung et al. (2013) and Raveendar et al. (2015).

The polymorphic information content (PIC) values varied between 0.23 (Lc_MCu11 and Lc_MCu97) and 0.77 (Lc_MCu17), and the average value was 0.44 (Table 3). The PIC values we obtained were found similar to the results obtained by Chung et al. (2013) and Raveendar et al. (2015).

Table 3- Genetic parameters for SSR markers

\begin{tabular}{lllll}
\hline Locus & $\boldsymbol{n}$ & $\boldsymbol{H e}$ & $\boldsymbol{H o}$ & $\boldsymbol{P I C}$ \\
\hline Lc_MCu11 & 2 & 0.27 & 0.00 & 0.23 \\
Lc_MCu17 & 8 & 0.79 & 0.17 & 0.77 \\
Lc_MCu95 & 4 & 0.34 & 0.08 & 0.30 \\
Lc_MCu97 & 2 & 0.27 & 0.00 & 0.23 \\
KF008505 & 6 & 0.61 & 0.17 & 0.53 \\
KF008507 & 5 & 0.68 & 0.27 & 0.63 \\
KF008512 & 5 & 0.48 & 0.03 & 0.41 \\
KF008526 & 3 & 0.48 & 0.11 & 0.40 \\
Total & 35 & 3.92 & 0.83 & 3.52 \\
Mean & 4.38 & 0.49 & 0.10 & 0.44 \\
\hline
\end{tabular}

$n$ : number of alleles, He: expected heterozygosity, Ho: observed heterozygosity, PIC: polymorphism information content

In the dendrogram, it was seen that 37 vetch accessions were divided into two main groups. While the first group comprised lines (V. ervilia) collected from Turkey, the second group included cultivars registered in Turkey. The genetic similarities of the first group were also found far from other vetch species (Figure 1). 


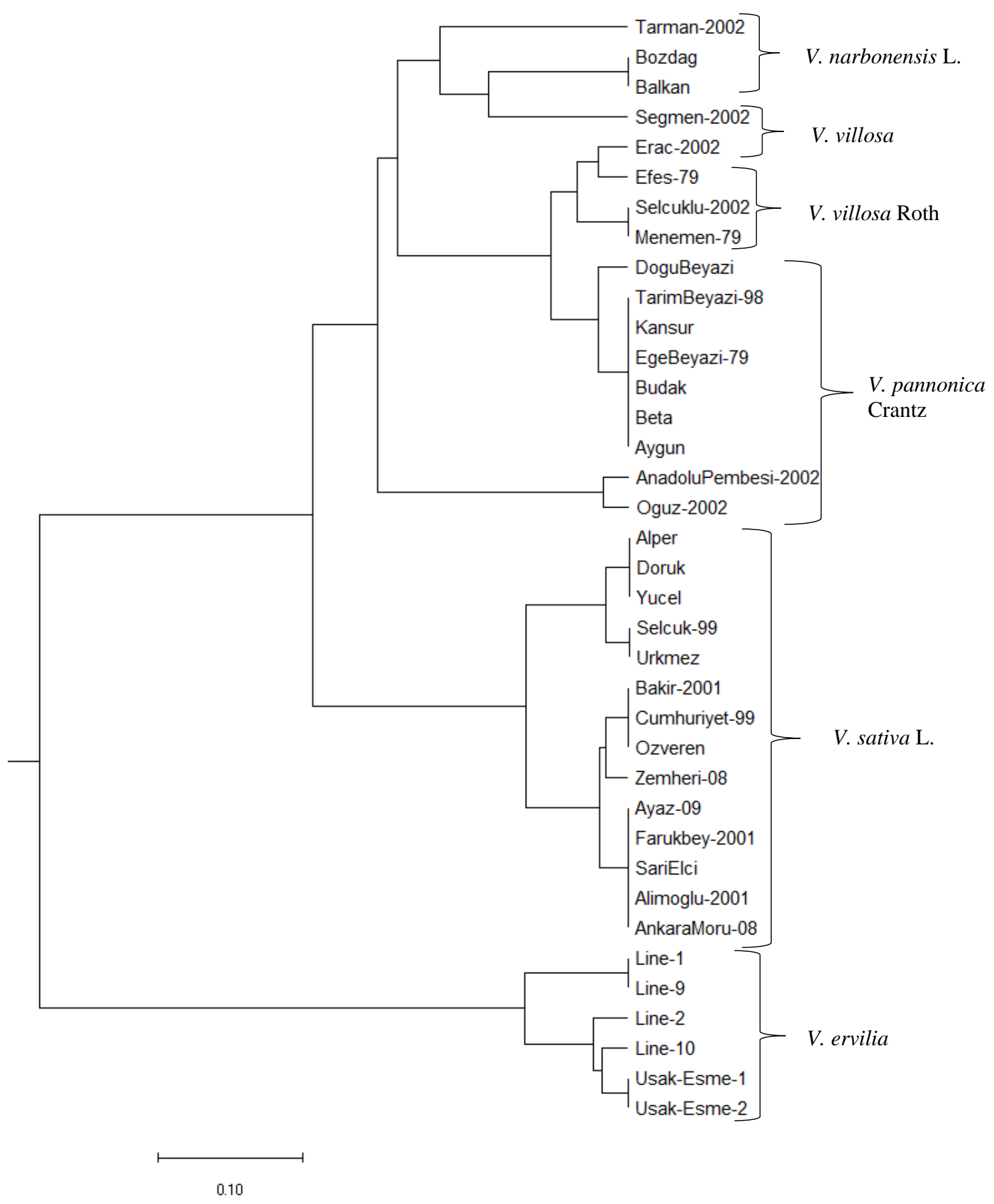

Figure 1- Genetic relationship dendrogram created using 8 polymorphic SSR markers in 37 vetch accessions

The majority of the cultivars, namely Beta, Aygun, Budak, Ege Beyazi-79, Kansur, Tarim Beyazi-98; Menemen-79, Selcuk2002; Balkan, Bozdag; Alper, Doruk, Yucel; Selcuk-99, Urkmez; Bakir-2001, Cumhuriyet-99, Ozveren; Ayaz-09, Farukbey2001, Sari Elci, Alimoglu-2001, Ankara Moru-08 were found to be genetically closer each other than the remaining accessions in the present study. This similarity may be due to the narrow structure of the vetch genome, and SSR markers used in this study might not be able to differentiate the narrow structure of the vetch genome, even if the markers provided an excellent distinction in the level of species. Furthermore, according to researchers in the research centers, the origin of registered cultivars might have arrived from the same resources to different research centers. The lowest genetic similarity rate among registered cultivars was observed between Dogu Beyazi and Alinoglu-2001, Alper, Ankara Moru-08, Ayaz-09, Doruk, Farukbey-2001, Yucel, Sari Elci (46\%). Among the lines which were collected in Turkey, Line 1 and Line 9, as well as Usak-Esme 1 line, Usak-Esme 2 line was found genetically closer. The only morphological differences between Usak-Esme 1 and Usak-Esme 2 is seed coat colour. While the Usak-Esme 1 has cream seed coat colour, Usak-Esme 2 has blackish seed colour. This result also supports that SSR loci used in this study do not distinguish the narrow genetic structure of the vetch genome. The genetic similarity between registered 
cultivars and collected lines varied between 0.32\% (Balkan and Usak-Esme, Usak-Esme Black 2; Bozdag and Usak-Esme, UsakEsme2; Zemheri-08 and Line 2) and 0.04\% (Menemen-79 and Line 1, Line 9, Line 10) (Figure 1).

Potokina et al. (2000) used RAPD markers for genetic analysis of vetch genotypes. They reported that there are considerable differences between the genetic similarity value for inter- versus intra-specific genetic relationships as observed in the present study. However, Raveendar et al. (2015), on the other hand, stated that the dendrogram created using 36 SSR markers clustered in three groups but was not seen a clear division among Vicia accessions. Besides, a close genetic relationship was determined between Vicia sativa ssp. nigra and V. sativa. cordata (98\%) using 8 RAPD markers (Agar et al. 2006). According to Potokina et al. (2002), the absence of a clear intra-species differentiation within V. sativa can be explained by three biological reasons; i) in the past, there has been a bottleneck of serious decrease in the number of individuals within the species, then the individuals spread rapidly to their existing areas without gaining distinct features, ii) the high probability of cross-pollination within the species (up to 10\%; (Hanelt \& Mettin 1989)) causes gene flow between populations and thus preventing the formation of different groups, iii) cross-pollination between seed materials brought to different regions by breeding studies and local materials can mask or eliminate area differences.

As a result, a genetic analysis of 37 vetch accessions was performed with 8 SSR markers showing polymorphism among a total of 18 SSR markers developed for common vetch and lentil. Besides, the rate of transferability of lentil markers grew for lentils to vetch species was also determined. According to the results, a high similarity rate was found between some cultivars. It has been determined that the markers used in the study make a relatively successful distinction among the species but were not shown difference within the high similarities species. It is thought that the results obtained from this study will contribute to molecular breeding studies and the conservation of genetic resources in vetch.

\section{Acknowledgements}

Thanks are extended to Betul-Ziya Eren Genome and Stem Cell Center of Erciyes University for their support throughout the experiments.

\section{References}

Agar G, Adiguzel A, Baris O, Sengul M, Gulluce M, Sahin F \& Bayrak O F (2006). FAME and RAPD Analysis of Selected Vicia Taxa from Eastern Anatolia, Turkey. In Annales Botanici Fennici (pp. 241-249). Finnish Zoological and Botanical Publishing Board

Avcioglu R, Hatipoglu R \& Karadag Y (2009). Vetches, Bitter Vetch and Black Lentils. In: TC. The Ministry of Agriculture and Forestry, General Directorate of Agricultural Production and Development. İzmir pp. 402-403

Bakır M \& Kahraman A (2019). Development of New SSR (Simple Sequence Repeat) Markers for Lentils (Lens culinaris Medik.) from Genomic Library Enriched with AG and AC Microsatellites. Biochemical genetics 57(2): 338-353. DOI: 10.1007/s10528-018-9893-2

Bouabid S, Kourda H C, Boussaha A, Naceur M B \& Khélil A Z (2018). Assessment of Genetic Diversity in Narbon vetch (Vicia narbonensis L.) Germplasm Using Morphological and Molecular Markers. Crop and Pasture Science 69(9): 904-914. DOI: 10.1071/CP18086

Bozkurt M (2009). The Determination of Relationships of Some Vicia L. Species Growing in the Mediterranean and Central Anatolia by the Using Molecular Methods. Master thesis, University of Selcuk, Konya, Turkey. Thesis no:237523 in Council of Higher Education Thesis Center.

Cheeke P R \& Shull L R (1985). Natural Toxicants in Feeds and Poisonous Plants. AVI Publishing, Westport, CN.

Chung J W, Kim T S, Sundan S, Lee S Y \& Cho G T (2013). Development of 65 Novel Polymorphic cDNA-SSR Markers in Common Vetch (Vicia sativa subsp. sativa) Using Next-Generation Sequencing. Molecules 18: 8376-8392. DOI: 10.3390/molecules18078376

Chung J W, Kim T S, Sundan S, Lee G A, Park J H, Cho G T, Lee H S, Lee J Y, Lee M C, Baek H J \& Lee S Y (2014). New cDNA-SSR Markers in the Narrow-Leaved Vetch (Vicia sativa subsp. nigra) Using 454 Pyrosequencing. Molecular Breeding 33(3): 749-754. DOI: 10.1007/s11032-013-9980-3

Davis P H (1970). Flora of Turkey and the East Aegean Islands. Edinburgh University Press, Edinburgh, pp. 328-369

Davis P H \& Plitmann U (1970). Vicia L. Flora of Turkey and East Aegean Islands. Edinburgh University Press, Edinburgh, Vol. 3

De la Rosa L, López-Román M I, González J M, Zambrana E, Marcos-Prado T \& Ramírez-Parra E (2021). Common Vetch, Valuable Germplasm for Resilient Agriculture: Genetic Characterization and Spanish Core Collection Development. Frontiers in Plant Science 12: 282. DOI: $10.3389 /$ fpls.2021.617873

Dutta S, Kumawat G, Singh B P, Gupta D K, Singh S, Dogra V, Gaikwad K, Sharma T R, Raje R S, Bandhopadhya T K, Datta S, Singh M N, Bashasab F, Kulwal P, Wanjari K B, Varshney R K, Cook D R \& Singh N K (2011). Development of Genic-SSR Markers by Deep Transcriptome Sequencing in Pigeonpea [Cajanus cajan (L.) Millspaugh]. BMC Plant Biology 11(1): 17. DOI: 10.1186/1471-2229-11-17

El Fatehi S, Béna G, Filali-Maltouf A \& Ater M (2016). Genetic Diversity of Moroccan Bitter Vetch 'Vicia ervilia'(L.) Willd. Landraces Revealed by Morphological and SSR Markers. Australian Journal of Crop Science 10(5): 717-725

Ertus M M, Sabanc1 C O \& Sensoy S (2016). Determination of Molecular Diversity with ISSR Markers in Some Cultivated Alfalfa (Medicago sativa L.) Ecotypes. Journal of Field Crops Central Research Institute 25(Special Issue-1): 249-254. DOI: 10.21566/tarbitderg.280503.

Genckan M S (1992). Forage Crops Production. Ege University Press, Izmir (in Turkish).

Hanelt P \& Mettin D (1989). Biosystematics of the Genus Vicia L. (Leguminosae). Annual Review of Ecology Systematics 20: 199-223. DOI: 10.1146/annurev.es.20.110189.001215

Ibanez S, Medina M I \& Agostini E (2020). Vicia: A Green Bridge to Clean up Polluted Environments. Applied Microbiology and Biotechnology 104(1): 13-21. DOI: 10.1007/s00253-019-10222-5

Kartal G K, Senbek G, Karaca M \& Acikgoz E (2020). Hybridization Studies in Vicia sativa Complex. Euphytica 216(2): 29. DOI: $10.1007 / \mathrm{s} 10681-020-2566-3$ 
Kıran Y, Gedik O \& Sahin A (2012). Karyological Investigate on Nine Species of Vicia Section from Vicia Genus Growing in Elazig and Surrounding. BEU. Journal of Science 1(1): 11-18, 2012 (1)1: 11-18

Kupicha F K (1976). The Infrageneric Structure of Vicia L. R. Bot. Gard. 32: 247-250

Larbi A, Hassan S, Kattash G, Abd El-Moneim A M, Jammal B, Nabila H \& Nakkoul H (2010). Annual Feed Legume Yield and Quality in Dryland Environments in North-West Syria: 2. Grain and Straw Yield and Straw Quality. Animal Feed Science and Technology $160:$ 90-97. DOI: $10.1016 /$ j.anifeedsci.2010.07.004

Lefort F, Lally M, Thompson D \& Douglas G C (1998). Morphological Traits, Microsatellite Fingerprinting and Genetic Relatedness of A Stand of Elite Oaks (Q. robur L.) at Tullynally, Ireland. Silvae Genetica 47:5-6

Liu K \& Muse S V (2005). PowerMarker: An Integrated Analysis Environment for Genetic Marker Analysis. Bioinformatics 21: $2128-2129$. DOI: 10.1093/bioinformatics/bti282

Maul J, Mirsky S, Emche S \& Devine T (2011). Evaluating a Germplasm Collection of the Cover Crop Hairy Vetch for Use in Sustainable Farming Systems. Crop Science 51(6): 2615-2625. DOI: 10.2135/cropsci2010.09.0561

Mengoni A, Gori A \& Bazzicalupo M (2000). Use of RAPD and Microsatellite (SSR) Variation to Assess Genetic Relationships Among Populations of Tetraploid Alfalfa, Medicago sativa. Plant breeding 119(4): 311-317. DOI: 10.1046/j.1439-0523.2000.00501.x.

Nei M (1973). Analysis of Gene Diversity in Subdivided Populations. The Proceedings of the National Academy of Science 70: $3321-3323$. DOI: $10.1073 /$ pnas.70.12.3321

Nunome T, Negoro S, Kono I, Kanamori H, Miyatake K, Yamaguchi H, Ohyama A \& Fukuoka H (2009). Development of SSR Markers Derived from SSR-Enriched Genomic Library of Eggplant (Solanum melongena L.). Theoretical and Applied Genetics 119(6): 1143-1153. DOI 10.1007/s00122-009-1116-0

O’Neill R, Snowdon R J \& Kohler W (2003). Population Genetics Aspects of Biodiversity. Progress in Botany 64: 115-137. DOI: 10.1007/9783-642-55819-1_7

Ozsensoy Y \& Kurar E (2012). Marker Systems and Applications in Genetic Characterization Studies. Journal of Cell and Molecular Biology 10(2): 11

Potokina E, Vaughan D A, Eggi E E \& Tomooka N (2000). Population Diversity of the Vicia sativa agg. (Fabaceae) in the Flora of the Former USSR Deduced from RAPD and Seed Protein Analyses. Genetic Resources and Crop Evolution 47(2): 171-183. DOI: 10.1023/A: 1008756420011

Potokina E, Blattner F, Alexandrova T \& Bachmann K (2002). AFLP Diversity in the Common Vetch (Vicia sativa L.) on the World Scale. Theoretical and Applied Genetics 105(1): 58-67. DOI: 10.1007/s00122-002-0866-8

Raveendar S, Lee G A, Jeon Y A, Lee Y J, Lee J R, Cho G T, Cho J H, Park J H, Ma K H \& Chung J W (2015). Cross-Amplification of Vicia sativa subsp. sativa Microsatellites Across 22 Other Vicia Species. Molecules, 20: 1543-1550. DOI: 10.3390/molecules20011543

Renna M, Gasmi-Boubaker A, Lussiana C, Battaglini L M, Belfayez K \& Fortina R (2014). Fatty Acid Composition of the Seed Oils of Selected Vicia L. Taxa from Tunisia. Italian Journal of Animal Science 13:2: 3193. DOI: 10.4081/ijas.2014.3193

Renzi J P, Chantre G R \& Cantamutto M A (2017). Self-Regeneration of Hairy Vetch (Vicia villosa Roth) as Affected by Seedling Density and Soil Tillage Method in a Semi-Arid Agroecosystem. Grass and Forage Science 72(3): 524-533. DOI: 10.1111/gfs.12255

Renzi J P, Chantre G R, Smýkal P, Presotto A D, Zubiaga L, Garayalde A F \& Cantamutto M A (2020). Diversity of Naturalized Hairy Vetch (Vicia villosa Roth) Populations in Central Argentina as a Source of Potential Adaptive Traits for Breeding. Frontiers in Plant Science 11: 189. DOI: $10.3389 /$ fpls.2020.00189

Schuelke M (2000). An Economic Method for the Fluorescent Labelling of PCR Fragments. Nature Biotechnology 18: 233-234. DOI: $10.1038 / 72708$

Tamura K, Dudley J, Nei M \& Kumar S (2007). MEGA4: Molecular Evolutionary Genetics Analysis (MEGA) Software Version 4.0. Molecular Biology and Evolution 24: 1596-1599. DOI: 10.1093/molbev/msm092

Tautz D (1989). Hypervariability of Simple Sequence as a General Source for Polymorphic DNA Markers. Nucl. Acids Res 7: 6463-6470. DOI: $10.1093 / \mathrm{nar} / 17.16 .6463$

Unverdi M A (2007). Research on the Determination of Morphological and Molecular Diversity Among Some Vetch Cultivars Registered in Turkey. Master thesis, University of Cukurova, Adana, Turkey. Thesis no:178605 in Council of Higher Eduation Thesis Center.

Van de Wouw M, Enneking D, Robertson L D \& Maxted N (2001). Vetches (Vicia L.). In: Maxted N, Bennett S.J. (eds) Plant Genetic Resources of Legumes in the Mediterranean. Current Plant Science and Biotechnology in Agriculture, vol 39. Springer, Dordrecht. DOI: 10.1007/978-94-015-9823-1_8

Zulkadir G \& İdikut L (2021). Genetic Diversity and Phylogenetic Relatıonships of Turkish Local Popcorn (Zea mays everta) Populations by Simple Sequence Repeats (SSRs). Journal of Agricultural Sciences 27(2): 170-178. DOI: 10.15832/ankutbd.626912

(C) 2022 by the author(s). Published by Ankara University, Faculty of Agriculture, Ankara, Turkey. This is an Open Access article distributed under the terms and conditions of the Creative Commons Attribution (CC BY) license (http://creativecommons.org/licenses/by/4.0/), which permits unrestricted use, distribution, and reproduction in any medium, provided the original work is properly cited. 